\title{
Wyroki Praskiej Izby Apelacyjnej w sprawach kryminalnych dla sądu w Slavkově u Brna w I połowie XVIII wieku
}

\author{
Daniel Wojtucki \\ Uniwersytet Wrocławski, Instytut Historyczny, Ul. Szewska 49, 48-300 Wrocław, Polska
}

Do redakce doručeno 2. května 2017; k publikaci přijato 6. listopadu 2017

\section{APPEALS COURT DECISION ON CRIMINAL VERDICTS OF THE COURT IN SLAVKOV NEAR BRNO IN THE FIRST HALF OF THE $18^{\mathrm{TH}}$ CENTURY}

ABSTRACT The Prague appeals court (Appellationsgericht) was founded on orders from Ferdinand I in the year 1548. In the beginning the judges addressed predominantly civilian-administrative verdicts. It wasn't before the end of the $17^{\text {th }}$ century that the court began hearings regarding also criminal verdicts. Legal decisions referred to Slavkov near Brno-Austerlitz on several occasions, in some years (e.g. in 1723 and 1732) repeatedly. According to the verdicts of Prague judges the capital punishment was the most frequent sentence against the defendants in the first half of the $18^{\text {th }}$ century. According to the Prague appeals court, the most frequent criminal acts tried in the Slavkov were murder (in the years 1710, 1711), infanticide (two cases in the year 1723), larceny (in the years 1731, 1732), falsification (in 1702), heresy (in 1706) and sale of stolen property (in 1725). Some of the convicted were members of the Jewish community (in 1725, 1731, 1732).

KEY WORDS Prague appeals court; gallows; modern age; capital punishment; the judiciary

\section{ROZHODNUTÍ APELAČNÍHO SOUDU TÝKAJÍCÍ SE KRIMINÁLNÎCH ROZSUDKU゚ SOUDU VE SLAVKOVĚ U BRNA V PRVNÍ POLOVINĚ 18. STOLETÍ}

\begin{abstract}
ABSTRAKT Pražský apelační soud (Appellationsgericht) byl založen nařízením Ferdinanda I. roku 1548. Z počátku se pražští soudci zabývali především rozsudky civilně - správními a teprve od konce 17. století pak i rozsudky kriminálními. Právní naučení se několikrát týkala také Slavkova u Brna. V některých letech, jako např. 1723 a 1732, rozhodovali slavkovské soudní verdikty i opakovaně. Podle rozhodnutí pražských soudců převažoval v první polovině 18. století u odsouzených ze Slavkova trest smrti jako vůbec nejčastější rozsudek. Podle záznamů pražského apelačního soudu byla nejčastěji souzeným trestným činem ve Slavkově vražda $(1710,1711)$, vražda dítěte nebo plodu (dva př́pady 1723$)$, krádež (1731, 1732), překupnictví (dva případy 1732), falzifikátorství (1702), kacířství (1706) a prodej kradených věcí (1725). Část odsouzených byla z židovské komunity $(1725,1731,1732)$.
\end{abstract}

KLÍČOVÁ SLOVA Pražský apelační soud; šibenice; novověk; trest smrti; justice

ABSTRAKT Praską Izbę Apelacyjną (niem. Appellationsgericht, czes. Apelační soud), powołano do życia instrukcją Ferdynanda I Habsburga w styczniu 1548 r. Pierwotnie ławnicy z Pragi rozpatrywali przede wszystkim sprawy cywilno-prawne, a dopiero pod koniec XVII stulecia głównie kryminalne. Z pouczeń prawnych korzystali także niejednokrotnie ławnicy ze Slavkova u Brna, w niektórych latach nawet kilkakrotnie, jak np. w latach: 1723 i 1732. Na podstawie zachowanych wyroków wydanych przez ławników z Pragi można stwierdzić, że w przypadku Slavkova w przesłanych orzeczeniach przeważała kara śmierci, jako główna sankcja wobec oskarżonych w I połowie XVIII w. Na podstawie wydanych wyroków przez Praską Izbę Apelacyjną można wnioskować, że najpopularniejszym przestępstwem za jakie ukarano skazanych w Slavkově było zabójstwo $(1710,1711)$, po nim plasuje się pozbawienie życia dziecka lub spędzenie płodu (dwa przypadki z $1723 \mathrm{r}$.), a następnie kradzież (1731 r. i 1732 r.), paserstwo (1732 r. - dwa przypadki), fałszerstwo (1702 r.), bluźnierstwo (1706 r.) i sprzedaż trucizny (1725 r.). Znaczna część przestępców skazanych wyrokiem Praskiej Izby Apelacyjnej była pochodzenia żydowskiego, np. w sprawach z lat: 1725, 1731 czy 1732. 
Odkrycie szubienicy w Slavkově u Brna (niem. Austerlitz) wiosną 2016 r. i szczątków osób na niej lub przy niej straconych, tudzież pochowanych, przyczyniło się do kolejnego kroku w badaniach nad tego typu stanowiskami na Morawach. Badania te zostały omówione szczegółowo w artykule, który opublikowany zostanie w prezentowanej publikacji (Unger 2017). Do najciekawszych odkryć niewątpliwie należą jamy wypełnione kośćmi ludzkimi, przy czym w jednej z nich odnaleziono kilka czaszek. Być może powstały one podczas któregoś z remontów tutejszej szubienicy, ponieważ w obowiązkach kata lub jego ludzi leżało posprzątanie miejsca straceń z zalegających tam resztek narzędzi egzekucyjnych i kości straconych. Przeważnie były one zakopywane właśnie w jamie obok szubienicy lub w jej wnętrzu (Wojtucki 2009, 189-190). Do takich odkryć dochodziło już na innych stanowiskach tego typu na terenie Europy. Należy przywołać tutaj przykład z estońskiego Tallinna, gdzie podczas badań tamtego miejsca straceń odkryto w jamie ponad 30 czaszek (Lavi 1995, 444). Do podobnego znaleziska doszło w szwajcarskim mieście Bern, a dokładniej w jego wschodniej części Schönberg, gdzie również odsłonięto m.in. jamę wypełnioną kośćmi ludzkimi, wśród których były i licznie występujące czaszki. Dodatkowo na szczątki zostały narzucone sporych rozmiarów kamienie (Baeriswy, Monnot, Ulrich-Bochsler 2010, 177).

Niestety nie zachowało się wiele informacji dotyczących sądownictwa w Slavkově, a co za tym idzie orzeczonych i wykonanych w tym mieście wyroków. W 1288 r. król Wacław II udzielił Krzyżakom (Řád německých rytírư) prawo wystawienia szubienicy koło miasta i karania na niej lub przy niej przestępstw poddanych. Dodatkowo ławnicy ze Slavkova mieli prawo odwoływania się w sprawach spornych o pouczenie prawne do Brna, co zostało potwierdzone w dokumencie z 1497 r. (Štarha 2001, 93). Uzyskanie praw sądowniczych, a zwłaszcza prawa karania na gardle (ius gladii), zobowiązało władze Slavkova do zorganizowania stosownego organu sądowniczego. Sprawy karne były rozpatrywane przez sąd kryminalny (judicium criminale). W podstawowym składzie zasiadali w nim: sędzia (Richter), wójt (Vogt) i ławnicy (Schöppen). Dodatkowo w sprawach większej wagi mógł włączyć się w sprawę sąd radziecki, biorący czynny udział w rozprawie i wydaniu wyroku (Maisel 1961, 87). Kodeks kryminalny cesarza Karola V z 1532 r., popularnie i powszechnie zwany $\mathrm{Ca}$ rolina, umocnił, jako dominujący, model inkwizycyjnego procesu karnego, na podstawie którego przyznanie się do winy oskarżonego było kluczowym aspektem do wydania wyroku skazującego. Musiało ono zostać złożone przed właściwym, kompetentnym i należycie obsadzonym sądem. Zgodnie z 12 artykułem Caroliny pozasądowe przyznanie się do winy było uznawane za poszlakę (Koredczuk 1999, 151).

Praską Izbę Apelacyjną (niem. Appellationsgericht, czes. Apelační soud), powołano do życia instrukcją Ferdynanda I Habsburga w styczniu $1548 \mathrm{r}$. Od tego roku, kto nie był zadowolony $\mathrm{z}$ wyroku rady miejskiej lub sądu, których orzeczenia nie były odtąd ostateczne, z któregokolwiek miasta królewskiego mógł odwołać się do Praskiej Izby Apelacyjnej za pośrednictwem rady miejskiej (Adamová 1975, 101; Koredczuk 1999,
139-150; Kreuz 2013, 231-250; Schmidt 1850; Wojtucki 2012, 167-176). Pierwotnie ławnicy z Pragi rozpatrywali przede wszystkim sprawy cywilno-prawne, a dopiero pod koniec XVII stulecia głównie kryminalne, o czym świadczą zachowane księgi. Powołanie Praskiej Izby Apelacyjnej należy uznać za jeden $\mathrm{z}$ pierwszych przejawów do utworzenia najwyższego sądownictwa podległego panującemu. W początkowym okresie znaczenie Praskiej Izby Apelacyjnej, jako instytucji odwoławczej było znikome. Od 1610 r. doprecyzowano, że do sądu w Pradze można odwołać się jedynie w prowadzonej sprawie o utratę czci, gardła lub majątku. Od roku 1627 miano zwracać się o pouczenie $\mathrm{w}$ przypadku, kiedy w czternaście dni nie wpłynął do miejskiego sądu formalny akt oskarżenia wobec uwięzionego, powstały wątpliwości o dopuszczeniu tortur lub karalności czynu przestępczego, albo oskarżeni wskazali jakąś osobę pochodzącą ze stanu wyższego lub mieszczanina z miasta królewskiego za współsprawcę (Adamová 1975, 109).

Praska Izba Apelacyjna składała się z prezydenta oraz radców, z których dwóch było ze stanu panów, dwóch rycerskiego, czterech mieszczan ze Starego i Nowego Miasta Praskiego oraz czterech doktorów praw. Po 1644 r. jej skład zwiększono do szesnastu radców, $\mathrm{z}$ których ośmiu nadal pochodziło ze stanów panów i rycerskiego, ale zmuszeni byli być obeznani $\mathrm{z}$ podstawami prawa. Druga ósemka to doktorzy praw, specjalizujący się w prawie karnym i cywilnym, znający język niemiecki i czeski (Koredczuk 1999, 139). Dodatkowo mile widziani byli też urzędnicy, którzy wykazywali zaznajomienie $\mathrm{z}$ realiami, prawem i zwyczajami na danym terytorium. Już od 1628 r. byli oni poddawani drobiazgowemu ustnemu egzaminowi z prawa cywilnego i karnego. Bez zezwolenia nie mogli oni opuścić Pragi, ich posiedzenia odbywały się w określonym z góry czasie (Adamová 1975, 105-106).

Pierwotnie Praska Izba Apelacyjna była instytucją odwoławczą dla sądów miejskich, dopiero pod koniec wieku XVI jej kompetencje rozszerzono też na inne sądy, jak również tego typu instytucje w państwach stanowych. W takim razie w gestii Praskiej Izby Apelacyjnej leżały wszystkie sprawy rozpatrywane przez sądy miejskie, jak i ziemskie. Zajmowano się głównie sprawami cywilnymi i kryminalnymi, czy zabierano głosy doradcze w sprawach sądowniczych (zastosowanie dodatkowego przesłuchania, $\mathrm{z}$ użyciem tortur lub bez, zatrzymania w więzieniu, powołaniu dodatkowych świadków). Ponadto osoby, wobec których sąd niższej instancji nakazał zastosowanie tortur mogły wnieść skargę do sędziów z Pragi (Koredczuk 1999, 166). Czasem to ci ostatni dla lepszego poznania sprawy, kiedy uznali, iż przesłany materiał zebrany $\mathrm{w}$ danej sprawie, z któregoś sądów jest niepełny lub niewystarczający, dla podjęcia ostatecznej decyzji sami nakazywali zastosowanie tortur. Przekrój spraw podnoszonych przez rady miejskie lub instytucje sądownicze w korespondencji z Praską Izbą Apelacyjną jest różnoraki. W myśl instrukcji z 1644 r. pierwszeństwo miały delikty kryminalne przed innymi sprawami, a rozpatrywane miały być co tydzień, w każdy poniedziałek (Koredczuk 1999, 139; Schmidt 1850, 22). Dlatego w księgach wyroków i pouczeń od drugiej połowy XVII w., a właściwie pod koniec tego stulecia, dominują orzeczenia 


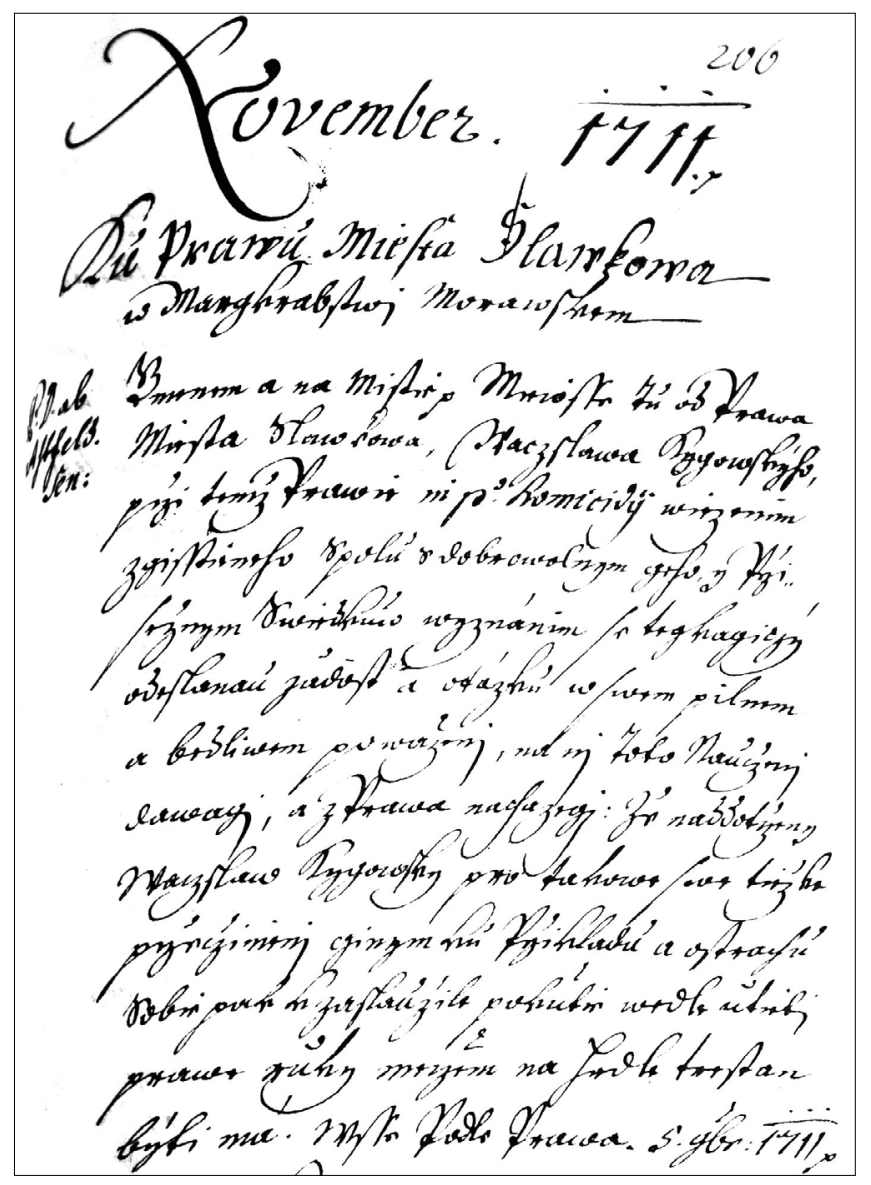

Obr. 1. Slavkov - wyrok kary śmierci wydany przez Praską Izbę Apelacyjną w listopadzie 1711 r. w sprawie o zabójstwo. NAP, AS, sygn. 148, s. 206r. Foto: D. Wojtucki.

wydane w sprawach karnych, przede wszystkim przeróżnych przestępstw natury kryminalnej (zabójstwa, kradzieże, napady rabunkowe, prostytucja, itp.). Jak to określono, do rozpatrzenia przez Praską Izbę Apelacyjną miały trafiać wszelkie sprawy ważne, trudne lub wątpliwe (Koredczuk 1999, 142). Instytucja ta zajmowała się również rewizjami posiadanych przez poszczególne ośrodki praw sądowniczych i przeglądu wyposażenia w urządzenia penitencjarne oraz wykonanych tam egzekucji. Niestety rewizje te $\mathrm{z}$ lat 1709 i 1722 nie objęły swoim zasięgiem miast i miasteczek z terenów Moraw (Wojtucki 2011, 33-42).

Zespół Apelační soud (pol. Praska Izba Apelacyjna) przechowywany obecnie w Archiwum Narodowym w Pradze (Národní Archiv, Praha) liczy kilkaset jednostek archiwalnych, z czego najliczniejszą grupę stanowią księgi wyroków i pouczeń prawnych dla władz miejskich oraz właścicieli dóbr. Wśród nich istnieje też wyraźny podział na wyroki i pouczenia dla ośrodków królestwa czeskiego (NAP, AS, sygn. 96-183, oraz księgi zawierające orzeczenia dla miast i właścicieli dóbr z pozostałych ziem korony czeskiej (NAP, AS, sygn. 184-280). Należy zauważyć, że pouczenia prawne wysyłane do Slavkova były wpisywane zarówno do księgi wyroków dla sądów czeskich i morawskich (Knihy českých ortelů), jak i śląskich (Kni-

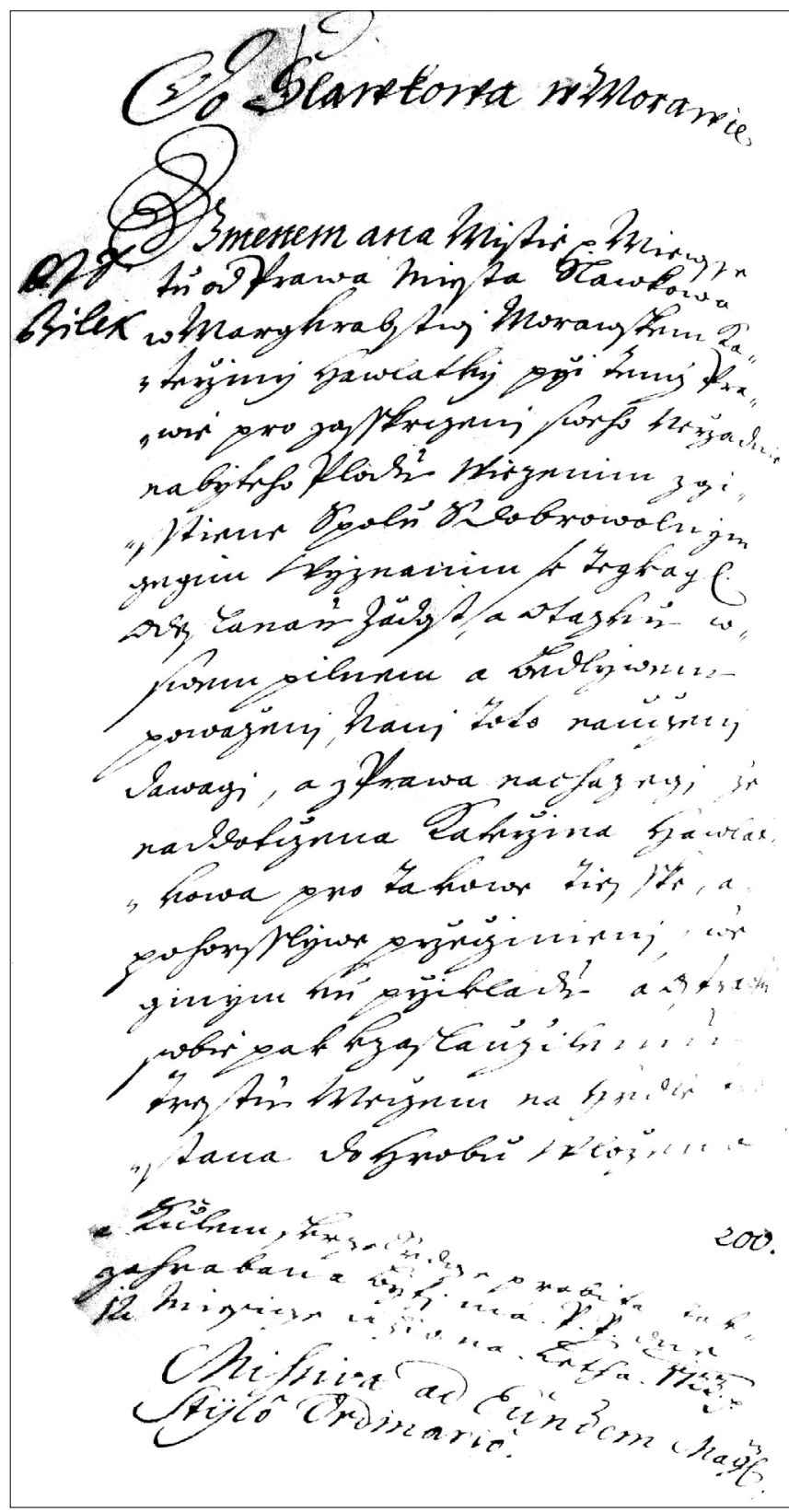

Obr. 2. Slavkov - wyrok kary śmierci poprzez ścięcie mieczem, włożenie ciała do grobu, przebicie serca palem z października 1723 r. NAP, AS, sygn. 155, s. 199v-200r. Foto: D. Wojtucki.

hy neměckých ortelů). Spisywano je w j. czeskim i niemieckim. Z pouczeń prawnych korzystali także niejednokrotnie ławnicy ze Slavkova, w niektórych latach nawet kilkakrotnie, jak np. w latach: 1723 i 1732.

Pożary, zniszczenia wojenne sprawiły, że często są to jedyne istniejące informacje o funkcjonowaniu sądu w tej miejscowości, posiadającego kompetencje w orzekaniu najwyższego wymiaru kary. Fakt ten czyni z zachowanych dokumentów źródło unikatowe do badań nad dawnym sądownictwem w tym mieście. Dokument wysłany przez Praską Izbę Apelacyjną był $\mathrm{w}$ zasadzie sformalizowany. Zawierał informacje o sprawie, której dotyczył, personalia osoby (osób) oskar- 


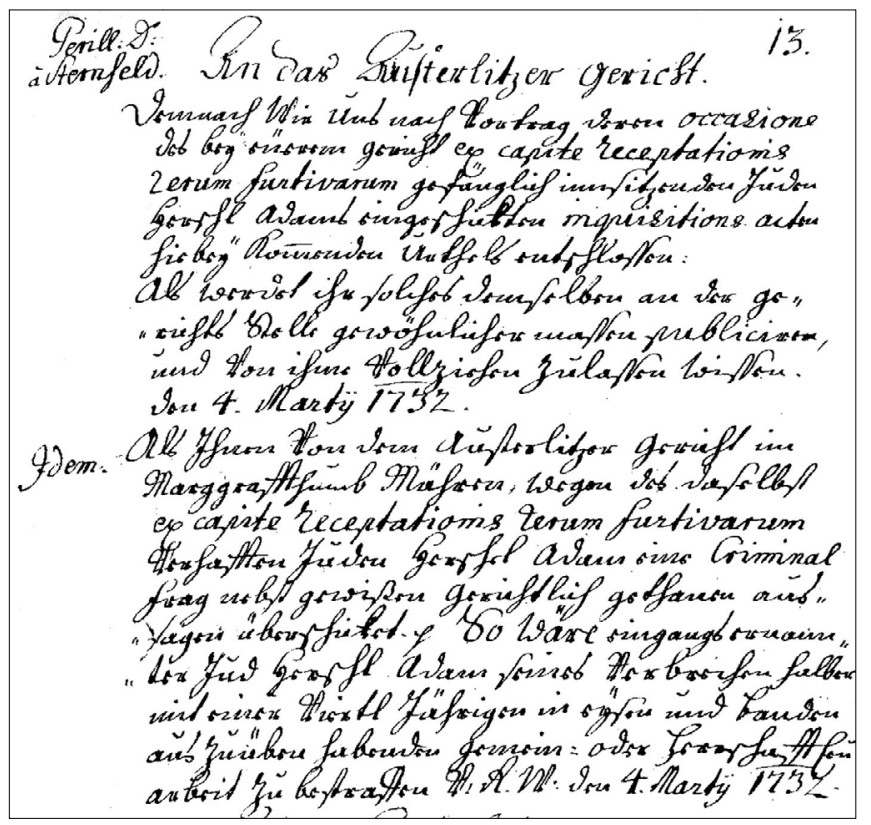

Obr. 3. Slavkov - wyrok pracy w łańcucach na Żyda Adama Herschla z marca 1732 r. skazanego za paserstwo. NAP, AS, sygn. 273, s. 13. Foto: D. Wojtucki.

żonej/ych, orzeczenie, jakie wydano w danej kwestii, rodzaj przestępstwa, które było przedmiotem danej sprawy. Miejsce i czas wydania, oraz niekiedy osobę, która była odpowiedzialna za prowadzenie danej sprawy, przeważnie w postaci dopisku na marginesie.

Na podstawie zachowanych wyroków wydanych przez ławników z Pragi można stwierdzić, że w przypadku Slavkova w przesłanych orzeczeniach przeważała kara śmierci, jako główna sankcja względem oskarżonych w I połowie XVIII w. Orzekano też wobec skazańców obu płci równie chętnie karę prac publicznych w kajdanach i aresztu. Ich okres zależny był od rodzaju przestępstwa i wynosił od kilku tygodni do pół roku. Przestępców skazywano również na wystawienie trzykrotne pod pręgierzem $\mathrm{z}$ mieczem katowskim $\mathrm{w}$ dłoniach, chłostę i wygnanie po wieczne czasy (1702 r.). Niemniej jednak najczęstszym sposobem pozbawienia życia osoby, którą skazano na karę śmierci w Slavkově była dekapitacja za pomocą miecza - meczem na hrdle trestán byti má $(1706,1710$, 1711, 1723 - dwa przypadki), przy czym w dwóch wyrokach z 1723 r. dodatkowo sankcję tą obostrzono włożeniem ciała do grobu i przebicia serca palem, po czym tak je pogrzebano - meczem na hrdle trestana, do hrobu wložena pak kulem skrze Srdcze probita a tak zahrabana (NAP, AS, sygn. 155, 199v-200r, 212r-212v). Natomiast wobec skazańca z 1706 r. nakazano dodatkowo spalenie ciała na granicy, zapewne przy szubienicy - na hraniczy uwézen, a tak spálen býti má (NAP, AS, sygn. 147, 37v-38r). Z kolei w przypadku z 1711 r. skazańcowi przed dekapitacją miano odciąć i prawą rękę - utieti prawe ruky meczem na hrdle trestan býti má (NAP, AS, sygn. $148,206)$. Chętnie również karano powieszeniem na miejskiej szubienicy (1731, 1732 - dwie osoby) - Prowazem na hrdle trestan byti ma (NAP, AS, sygn. 161, 71r-72r; sygn. 272, 438r- -438v). Wielokrotnie Praska Izba Apelacyjna orzekała wobec slavkovskich skazańców pracę w kajdanach na rzecz miasta lub gminy - mit einer Viertl Jährigen in eÿsen und banden auszuüben habenden gemein=oder Herschaffll. arbeit zu zubestraffen. Należała ona do łagodniejszych form kary, a osoba wobec, której zawyrokowano tą sankcję, zmuszona była pracować nie otrzymując zapłaty, przez określony czas na rzecz danego ośrodka. Można się domyśleć, że do jej zadań należało wykonywanie prac szczególnie uciążliwych, by nie rzecz hańbiących jak sprzątanie ulic, czy czyszczenie rynsztoków.

Przekrój popełnionych przestępstw w Slavkově w omawianym okresie w dokumentach rozpatrywanych przez Praską Izbę Apelacyjną jest różnoraki. Przeważnie wymieniano konkretny zakazany czyn w wydanym wyroku lub rzadziej bardziej ogólnie zapisywano, że skazana osoba jest winna - ärgerlichen und schweren Verbrechen/pro tak tiesske pržecžinieni swe, za co wymierzona jej kara ma być przestrogą i przykładem dla innych - anderen zum abscheü und beÿspiel/jinym ku pržikladu a ostrachu. Każdy dokument zakańczano datą jego wydania i zwrotem: „Z mocy prawa” - von Rechts wegen lub jego skrótem - v.R.w - Podle Práwa.

Na podstawie wydanych wyroków przez Praską Izbę Apelacyjną można wnioskować, że najpopularniejszym przestępstwem za jakie ukarano skazanych w Slavkově było zabójstwo $(1710,1711)$, po nim plasuje się pozbawienie życia dziecka lub spędzenie płodu (dwa przypadki z 1723 r.), a następnie kradzież (1731 r. i 1732 r.), paserstwo (1732 r. - dwa przypadki), fałszerstwo (1702 r.), bluźnierstwo (1706 r.) i sprzedaż trucizny (1725 r.). Należy jednak zaznaczyć, że mamy jedynie wgląd w sprawy, które wysłano do ponownego rozpatrzenia w wyższej instancji. Nie wiadomo jednak ile wyroków skazujących zapadło w pierwszej instancji, przed miejscowym sądem, w których wina oskarżonego była bezsporna i po których nie zdecydowano się na apelację.

Znaczna część przestępców skazanych wyrokiem Praskiej Izby Apelacyjnej była pochodzenia żydowskiego, np. w sprawach z lat: 1725, $1731 \mathrm{czy} 1732$. W pierwszym przypadku osądzono Żyda Lazara Kakerle - wegen Gifft verkauffung (NAP, AS, sygn. 157, 298r-299r). W drugim niejakiego Philippa Moÿsesa (Moisa) i Wolfa Mandla oskarżono o ex capite furti i wymierzono karę śmierci przez powieszenie. Dodatkowo wyrok miał zostać odczytany w dniu egzekucji zarówno przed sądem, ale też na miejscu straceń przy szubienicy. Spowodowane to było zapewne za przyczyną innego Żyda Adama Herschla (Herrschla), którego skazano dopiero rok później za paserstwo, ponieważ planowano dowiedzieć się od niego, dlaczego rzeczy innego Żyda, Abrahama Moisesa z miejscowości Bučovice, zostały przeniesione do jego domu (NAP, AS, sygn. 272, 438r-438v). Z kolei w 1732 r. wśród oskarżonych byli tym razem m.in. Żyd Jakob Herrschl znany też jako „Kozerle”, wraz z małżonką, których posądzono o zakup kradzionego zboża od dwóch złodziei, powieszonych najpewniej według zasądzonego wyroku na slavkovskiej szubienicy (NAP, AS, sygn. 161, s. 71r-72r). W świetle zachowanych dokumentów można wnioskować, ̇̇e przeważnie Żydów oskarżano o kradzieże, fałszerstwo i paserstwo. Jeden Żyd 
Wyroki wydane przez Praską Izbę Apelacyjną dla ławników ze Slavkova u Brna w I połowie XVIII wieku.

\begin{tabular}{|c|c|c|c|c|}
\hline $\begin{array}{l}\text { Data orzeczenia } \\
\text { wyroku }\end{array}$ & $\begin{array}{l}\text { Imię i nazwisko } \\
\text { osoby skazanej }\end{array}$ & Przestępstwo & Orzeczona kara & Źródło \\
\hline 31.08 .1702 & Żyd & Sprawa o fałszerstwo & $\begin{array}{l}\text { Trzykrotne wystawienie } \\
\text { z mieczem katowskim pod } \\
\text { pręgierzem, chłosta, złożenie } \\
\text { przysięgi i wygnanie po wieczne } \\
\text { czasy }\end{array}$ & $\begin{array}{l}\text { NAP, AS, sygn. } 265 \text {, } \\
\text { s. } 106 \mathrm{r}-106 \mathrm{v} .\end{array}$ \\
\hline 20.07.1706 & Michal Subert & Bluźnierstwo & $\begin{array}{l}\text { Scięcie mieczem, przewiezienie } \\
\text { na granicę i spalenie ciała }\end{array}$ & $\begin{array}{l}\text { NAP, AS, sygn. } 147 \text {, } \\
\text { s. } 37 \mathrm{v}-38 \mathrm{r}\end{array}$ \\
\hline 27.02 .1710 & Mikulas Skarzipka & Zabójstwo & Ścięcie mieczem & $\begin{array}{l}\text { NAP, AS, sygn. } 148 \text {, } \\
\text { s. } 90 \mathrm{v}\end{array}$ \\
\hline 5.11 .1711 & Waczlaw Kygowsky & Zabójstwo & Ucięcie prawicy, ścięcie mieczem & $\begin{array}{l}\text { NAP, AS, sygn. } 148 \text {, } \\
\text { s. } 206 \text { r. }\end{array}$ \\
\hline 12.10 .1723 & Katerzina Hawlatkowa & Spędzenie płodu & $\begin{array}{l}\text { Ścięcie mieczem, włożenie ciała } \\
\text { do grobu, przebicie serca palem } \\
\text { i pogrzebanie }\end{array}$ & $\begin{array}{l}\text { NAP, AS, sygn. } 155 \text {, } \\
\text { s. 199v-200r }\end{array}$ \\
\hline 15.11 .1723 & $\begin{array}{l}\text { Maria Anna Dinlowa, } \\
\text { Arnost Baubing }\end{array}$ & $\begin{array}{l}\text { Zabójstwo dziecka, } \\
\text { prostytucja }\end{array}$ & $\begin{array}{l}\text { Kobieta ścięcie mieczem, } \\
\text { włożenie ciała do grobu, } \\
\text { przebicie serca palem } \\
\text { i pogrzebanie. Mężczyzna sześć } \\
\text { tygodni aresztu }\end{array}$ & $\begin{array}{l}\text { NAP, AS, sygn. } 155 \text {, } \\
\text { s. } 212 \mathrm{r}-212 \mathrm{v} .\end{array}$ \\
\hline 13.07.1725 & Lazar Kakerle & Sprzedaż trucizny & $\begin{array}{l}\text { Pół roku pracy w łańcuchach } \\
\text { na rzecz gminy lub dominium }\end{array}$ & $\begin{array}{l}\text { NAP, AS, sygn. 157, } \\
\text { s. 298r-299r. }\end{array}$ \\
\hline 16.09.1728 & Wentzl Habert & Zabójstwo & Uniewinnienie & $\begin{array}{l}\text { NAP, AS, sygn. } 272 \text {, } \\
\text { s. } 121 \mathrm{r}-121 \mathrm{v} .\end{array}$ \\
\hline 26.11 .1731 & $\begin{array}{l}\text { Philipp Moÿses } \\
\text { (Mois), Wolf Mandl }\end{array}$ & Kradzież & Powieszenie & $\begin{array}{l}\text { NAP, AS, sygn. } 272 \text {, } \\
\text { s. } 438 \mathrm{r}-438 \mathrm{v} \text {. }\end{array}$ \\
\hline 4.03 .1732 & $\begin{array}{l}\text { Adam Herschl } \\
\text { (Herrschl) }\end{array}$ & Paserstwo & $\begin{array}{l}\text { Kwartał pracy w łańcuchach } \\
\text { na rzecz gminy lub dominium }\end{array}$ & $\begin{array}{l}\text { NAP, AS, sygn. } 273 \text {, } \\
\text { s. } 13 .\end{array}$ \\
\hline 22.08 .1732 & $\begin{array}{l}\text { Jakub Kapusta, Martin } \\
\text { Petru, Jacob Herrschl } \\
\text { wraz z żoną }\end{array}$ & $\begin{array}{l}\text { Dwóch pierwszych } \\
\text { kradzież, trzeci } \\
\text { paserstwo }\end{array}$ & $\begin{array}{l}\text { Dwóch pierwszych mężczyzn } \\
\text { powieszenie, trzeci - pół roku } \\
\text { pracy w łańcuchach. Kobieta } \\
\text { miała zostać zwolniona } \\
\text { z więzienia }\end{array}$ & $\begin{array}{l}\text { NAP, AS, sygn. 161, } \\
\text { s. 71r-72r. }\end{array}$ \\
\hline
\end{tabular}

wzmiankowany we slavkovskich dokumentach zawisł najpewniej jeszcze w 1702 r. na belce szubienicy w Lipníku nad Bečvou, na podstawie wyroku z dnia 1 września tegoż roku (NAP, AS, sygn. 265, 109v). Żydów postrzegano wówczas jako element sprzyjający światkowi przestępczemu. Stanowili oni istotną pozycję wśród nabywców kradzionych przedmiotów. Byli oni niewątpliwie wręcz doskonałymi paserami, niezadającymi zbędnych pytań o pochodzenie dostarczonych do nich przedmiotów, ale przy tym także ludźmi majętnymi, płacący- mi gotówką za przyniesione do nich towary i kosztowności. $\mathrm{Na}$ koniec należy wspomnieć, że nie wszystkie wyroki wydane przez miejscowy sąd wymagały pouczenia prawników z Pragi. Część z nich mogła być jedynie prośbą o konsultację prawną, w sprawie wydanego wyroku, który ławnicy z zamku praskiego, na podstawie nadesłanych materiałów jedynie potwierdzali. Odwołanie do Praskiej Izby Apelacyjnej przedłużało sprawę w czasie, a tym samym wyegzekwowanie wyroku. Do tego sędziowie z Pragi mogli zmienić na korzyść oskarżo- 
nego wyrok pierwszej instancji lub niekorzyść, obostrzając go o dodatkowe czynności egzekucyjne, jak wleczenie na miejsce straceń, odjęcie dłoni, rwanie cęgami, wypalenie piętna $i$ inne. Niemniej jednak po otrzymaniu sentencji z Pragi miejscowy sąd potrzebował od kilku tygodni do nawet kilku miesięcy na wykonanie orzeczonego wyroku, w przypadku kary śmierci, kiedy należało zadbać o wypożyczenie kata, jeśli dany ośrodek go nie zatrudniał. Starano się jednak, aby nie przeciągało się to zbytnio w czasie, ze względu na rosnące koszty (konieczność wyżywienia czekającego na kaźń przestępcy, czy wypłacenia wynagrodzenia dla pilnujących go strażników).

\section{WYKAZ SKRÓTÓW}

AS - Apelační soud.

NAP - Národní Archiv, Praha.

s. - strona.

sygn. - sygnatura.

\section{ŹRÓDłA}

Národní Archiv w Pradze, Apelační soud, sygn. 147, 148, 155, 157, 161, 265, $272,273$.

\section{LITERATURA}

Adamová, K. (1975): Apelační soud v českém království v letech 1548-1651. In: Pocta akademiku Václavu Vaněčkovi k 70. narozeninám. Praha.

Baeriswy, A. - Aeriswy, A. - Monnot, D. - Ulrich-Bochsler, S. (2010): Bern BE, Brechbühlerstrasse 4-18, Schönberg Ost - Die bernische Richtstätte „untenaus“. In: J. Auler, Hrsg. Richtstättenarchäologie 2. Dormagen, 174-178.

Koredczuk, J. (1999): Ordynacja kryminalna Józefa I z 1707 roku. Z dziejów procesu karnego na Śląsku w pierwszej połowie XVIII wieku. Wrocław.

Kreuz, P. (2013): Das Appellationsgericht in Prag 1548-1783. Forschung, Quellen und historische Entwicklung. Beiträge zur Rechtsgeschichte Österreichs, 3(1), 231-250.
Lavi, A. (1995): Tallinner Vōllamägi (Galgenberg) - die mittelalterliche Hinrichtungstätte. Eesti Teaduste Akadeemia Toimetised. Humanitaar-ja Sotsiaalteadused, 44(4), 442-447.

Maisel, W. (1961): Sadownictwo miasta Poznania do końca XVI wieku. Poznań.

Schmidt, J. F. (1850): Monographie des kaiserl. königl. Böhm. AppellationsGerichtes seit dessen Errichtung als Appellationskammer in dem Jahre 1548 bis zu dessen im Jahre 1850 erfolgter Umwandlung in das kais. kön. Oberlandesgericht des zu dem constitutionellen Kaiserthume Oesterreich gehörigen Kronlandes Böhmen. Prag.

Štarha, I. (2001): Hrdelní soudy na Vyškovsku. Vyškovský sborník, II, 86-95.

Unger, J. (2017): Archeologický výzkum slavkovské šibenice u Křenovic (okres Vyškov). Anthropologia integra, 8(2), 7-13.

Wojtucki, D. (2009): Publiczne miejsca straceń na Dolnym Śląsku od XV do połowy XIX wieku. Katowice.

Wojtucki, D. (2011): Objekty výkonu práva na území Českého království podle revize hrdelního soudnictví v letech 1709-1722. In: Sborník Společnosti pro výzkum kamenných kř́žư $27-41$.

Wojtucki, D. (2012): Korespondencja Praskiej Izby Apelacyjnej z miastami na Śląsku w latach 1548-1740. Klio, 23(4), 167-176.

\section{AUTOR}

Wojtucki, Daniel, Dr. - historyk i archiwista, adiunkt w Zakładzie Historii Polski i Powszechnej XVI-XVIII wieku w Instytucie Historycznym Uniwersytetu Wrocławskiego. Jego tematem rozprawy doktorskiej obronionej w 2011 r. był „Kat i jego warsztat pracy na Śląsku, Górnych Łużycach i w hrabstwie kłodzkim od XVI do połowy XIX wieku". Do jego zainteresowań badawczych należą zagadnienia związane z dawnym wymiarem sprawiedliwości, archeologią prawną, historią nowożytną Śląska, a także wybrane aspekty dziejów wojskowości. Autor dwóch monografii oraz kilkudziesięciu artykułów opublikowanych w kraju i za granicą. Prezes Stowarzyszenia Ochrony i Badań Zabytków Prawa, w ramach którego współorganizował i uczestniczył w badaniach archeologicznych dawnych miejsc straceń na Śląsku i Górnych Łużycach.

Kontakt: Dr. Daniel Wojtucki. Uniwersytet Wrocławski, Instytut Historyczny. Ul. Szewska 49, 48-300 Wrocław, Polska/Polsko E-mail: daniel.wojtucki@centrum.cz 